\title{
Instantaneous and Quantitative Functionalization of Gold Nanoparticles with Thiolated DNA Using a pH-Assisted and Surfactant-Free Route
}

\author{
Xu Zhang ${ }^{\dagger,}$, Mark R. Servos ${ }^{\ddagger}$ and Juewen Liu ${ }^{\dagger *}$ \\ 'Department of Chemistry and Waterloo Institute for Nanotechnology, "Department of Biology, University of Waterloo, 200 \\ University Avenue West, Waterloo, Ontario, Canada N2L 3G1. \\ Supporting Information Placeholder
}

\begin{abstract}
The attachment of thiolated DNA to gold nanoparticles (AuNPs) has enabled many landmark works in nanobiotechnology. This conjugate chemistry is typically performed using a salt-aging protocol, where in the presence of an excess amount of DNA, $\mathrm{NaCl}$ is gradually added to increase DNA loading over 1-2 days. To functionalize large AuNPs, surfactants need to be used, which may generate difficulties for downstream biological applications. We report herein a novel method using a pH 3.0 citrate buffer to complete the attachment process in a few minutes. More importantly, it allows for quantitative DNA adsorption, eliminating the need to quantify the number of adsorbed DNA and allowing the adsorption of multiple DNAs with different sequences at predetermined ratios. The method has been tested for various DNAs over a wide range of AuNP sizes. Our work suggests a synergistic effect between $\mathrm{pH}$ and salt in DNA attachment and reveals the fundamental kinetics of AuNP aggregation versus DNA adsorption, providing a novel means to modulate the interactions between DNA and AuNPs.
\end{abstract}

The field of nanobiotechnology has emerged since 1996 with the landmark work for attaching thiolated DNA to gold nanoparticles, ${ }^{1,2}$ allowing the programmability, molecular recognition and catalytic property of biopolymers to couple to the optical, thermal, electric and catalytic property of inorganic nanomaterials. Numerous applications have since been made possible, including the preparation of ordered nanoparticle structures, ${ }^{3}$ biosensing, ${ }^{4}$ separation, ${ }^{5}$ and gene and drug delivery. ${ }^{6}$ At the same time, many distance-dependent physical properties related to nanoparticles in term of heat, electron and energy transfer ${ }^{7}$ as well as polyvalent binding ${ }^{8}$ have been systematically studied using DNA as a rigid spacer, adding new insights into nanoscience.

To enable these applications, a crucial step is to attach thiolated DNA to gold nanoparticles (AuNPs) and to ensure that the conjugate is stable at least under physiologic buffer conditions for DNA hybridization. ${ }^{9-11}$ The most commonly used $13 \mathrm{~nm}$ AuNPs are usually prepared using a citrate reduction method and are stabilized by the negative charges from the weakly adsorbed citrate ions. Even very low concentrations of salt (e.g. $50 \mathrm{mM} \mathrm{NaCl}$ ) can induce irreversible aggregation of such AuNPs. DNA is highly negatively charged and thus repelled by AuNPs. This charge repulsion posed an initial technical difficulty, since if a high concentration of $\mathrm{NaCl}$ is added to screen the charge, AuNP aggregation occurs before a high density of DNA is attached. This problem has been elegantly solved by using a process known as "salt aging", where $\mathrm{NaCl}$ was step-wise added to the DNA/AuNP mixture. ${ }^{9,10}$ It was later discovered that the density of attached DNA is proportional to the final $\mathrm{NaCl}$ concentration. ${ }^{12-14}$ The attached DNA enhances AuNP stability so that even more $\mathrm{NaCl}$ can be added to further increase DNA loading. This iterative process (Figure 1A) takes 1-2 days to form a stable conjugate, ${ }^{9,15,16}$ and the stability of this gold-thiol bond has also been systematically studied. ${ }^{17,18}$

This procedure works less well for larger AuNPs (e.g. $50 \mathrm{~nm})$ and it requires even more steps of salt addition. ${ }^{19,20}$ In 2006, it was reported that AuNPs up to $250 \mathrm{~nm}$ could be stably functionalized in the presence surfactants such as sodium dodecylsulfate. ${ }^{12}$ The step-wise addition of $\mathrm{NaCl}$ is still required though, taking at least a full day. This discovery has allowed for systematic size-dependent research to be carried out. ${ }^{16,21}$ In 2009, a fluorinated surfactant was reported to achieve rapid DNA loading in $\sim 2 \mathrm{hrs}$, where even $1 \mathrm{M} \mathrm{NaCl}$ could be added all at once. ${ }^{22}$ Surfactants were first adsorbed so that AuNPs could withstand high $\mathrm{NaCl}$ concentration, which in turn facilitated rapid DNA adsorption and displacement of surfactants. The use of surfactants, especially fluorinated surfactants, is undesirable for many applications including drug delivery since surfactants might be toxic to cells.

A

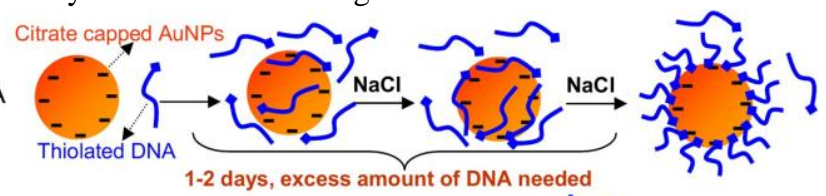

B
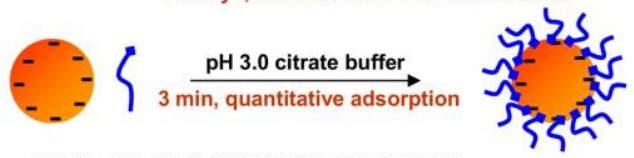

C DNA1 SH-AAAAAAAAACCCAGGTTCTCT DNA2 SH-CCCAGGTTCTCT

DNA3 TCACAGATGCGTAAAAAAAAA-SH

DNA4 TCACAGATGCGT-SH

DNA5 SH-TTTTTTTTTACGCATCTGTGA

DNA6 GGTGGTGGTGGTTGTGGTGGTGGTGGAAAAAAAA-SH

DNA7 SH-T(FAM)CCCAGGTTCTCT

DNA8 FAM-ATGCGGAGGAAGGTTTT-SH

DNA9 SH-TTTACCTGGGGGAGTAT-TMR

DNA10 SH-AAACCCTTGACCAGGCTCTTTT 
Figure 1. Schematics of attaching negatively charged thiolated DNA to Therefore, the quality of AuNPs was comparable for the two negatively charged AuNPs using the salt aging method (A) and the low methods and no AuNP aggregation was detected.

$\mathrm{pH}$ assisted method (B). (C) Sequences (listed from $5^{\prime}$ to $3^{\prime}$ ) and modifications of the DNAs used in this work.

The above experiments indicate that stable conjugates can be achieved in a few minutes at $\mathrm{pH}$. To gain quantitative

In all the previous work, an excess amount of DNA was added and understanding, the reaction kinetics was monitored in 10 mM non-conjugated DNA had to be removed. To quantify the number of citrate $\cdot \mathrm{HCl}$ buffers of different $\mathrm{pH}$. For this purpose, a thiol and DNA attached to each AuNPs, fluorescently labeled DNAs are often FAM (6-carboxylfluorescein) dual labeled DNA was used used, ${ }^{14}$ or DNA staining dyes have to be employed to prepare (DNA8). DNA adsorption brings FAM close to AuNP to induce calibration curves. The situation is getting even more complicated fluorescence quenching. Since FAM is pH sensitive, the kinetic when several different DNAs need to be attached at a certain ratio. measurement was performed by transferring a small volume of Since different DNAs may have different adsorption rates, the added the DNA/AuNP mixture (DNA:AuNP = 75:1) into a large ratio is unlikely to be the final ratio on AuNP. Therefore, a method volume of $\mathrm{pH} 7.6$ buffer at designated time points. As shown in for fast, quantitative, and surfactant-free DNA loading is needed to Figure 3A, > 80\% DNA adsorption was achieved in the first 2 further advance this field. Herein we communicate such a method to $\min$ at $\mathrm{pH} 3$. DNA adsorption gradually decreased with achieve all these goals (Figure 1B). The only required reagent is a increasing pH. At pH 7.0, only $40 \%$ DNA adsorbed. Therefore, low $\mathrm{pH}$ citrate buffer. Most previous work on tuning the AuNP/DNA DNA adsorption is a strong function of $\mathrm{pH}$. interaction employs only salt, ${ }^{19,23-25}$ while the effect of $\mathrm{pH}$ remains largely unexplored. ${ }^{18,26}$ Our discovery reveals a new way to control DNA adsorption, which is quite different from using salt and is likely to find applications in many areas involving AuNPs and DNA.
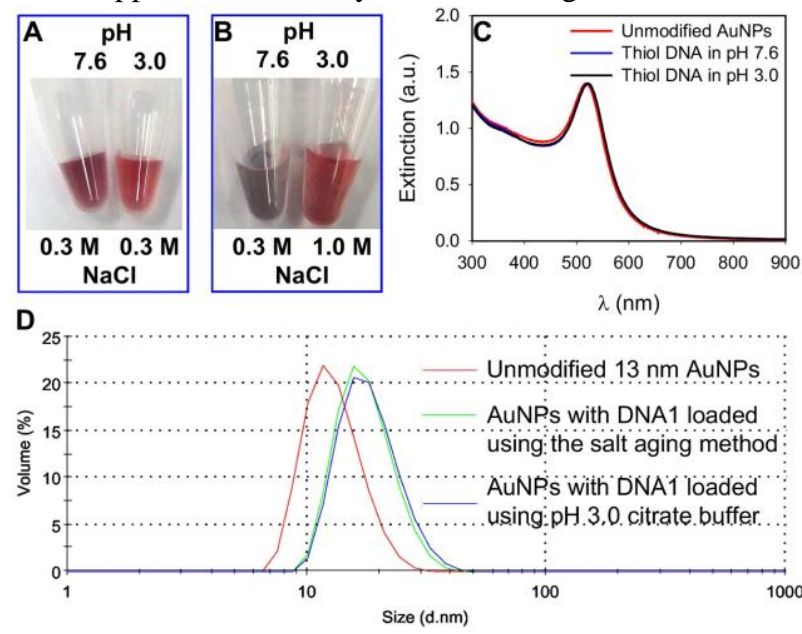

Figure 2. (A) Photograph of AuNPs mixed with DNA1 for 3 min at $\mathrm{pH}$ 7.6 or $\mathrm{pH} 3.0$ followed by adding $0.3 \mathrm{M} \mathrm{NaCl}$. (B) The samples were prepared the same way as in (A) but the free DNAs were removed and AuNPs were re-dispersed in buffers containing $0.3 \mathrm{M} \mathrm{NaCl}, \mathrm{pH} 7.6$ or in $1.0 \mathrm{M} \mathrm{NaCl}, \mathrm{pH}$ 7.6. Characterization of DNA1-functionalized AuNPs using UV-vis spectroscopy (C) and dynamic light scattering (D).

To test the effect of $\mathrm{pH}$, two tubes each containing $10 \mathrm{nM}$ of citrate-capped $13 \mathrm{~nm}$ AuNPs were mixed with 3 वM DNA1 (see Figure $1 \mathrm{C}$ for DNA sequence) for $1 \mathrm{~min}$ before the samples were respectively adjusted to $\mathrm{pH} 7.6$ and 3.0. After $3 \mathrm{~min}, 0.3 \mathrm{M} \mathrm{NaCl}$ was added. The sample in $\mathrm{pH} 7.6$ immediately turned purple, indicating AuNP aggregation, but the one in $\mathrm{pH} 3.0$ remained red (Figure 2A). Next, $200 \mu \mathrm{L}$ of each AuNPs were centrifuged to remove the supernatant and the pallets were dispersed in a typical buffer for DNA hybridization $(300 \mathrm{mM} \mathrm{NaCl}, 10 \mathrm{mM}$ HEPES, $\mathrm{pH}$ 7.6). Again, the $\mathrm{pH} 7.6$ sample turned blue right away but the $\mathrm{pH} 3.0$ one remained red even with $1 \mathrm{M} \mathrm{NaCl}$ (Figure 2B). Therefore, only the DNA attachment step needs to be performed at low $\mathrm{pH}$. After that, the $\mathrm{pH}$ can be adjusted to neutral. To confirm the quality of AuNPs after DNA attachment, the AuNPs were characterized using UV-vis spectroscopy (Figure 2C). The spectra were almost identical for the unmodified AuNPs, AuNPs attached with DNA1 using the conventional salt aging method, and with the low $\mathrm{pH}$ method. Next the AuNPs were studied using dynamic light scattering (Figure 2D). The hydrodynamic size of unmodified AuNPs was $13.5 \mathrm{~nm}$. Using the salt-aging method, the size changed to $18.6 \mathrm{~nm}$ due to the attached DNA. Using the $\mathrm{pH} 3.0$ buffer, the size was $17.9 \mathrm{~nm}$.
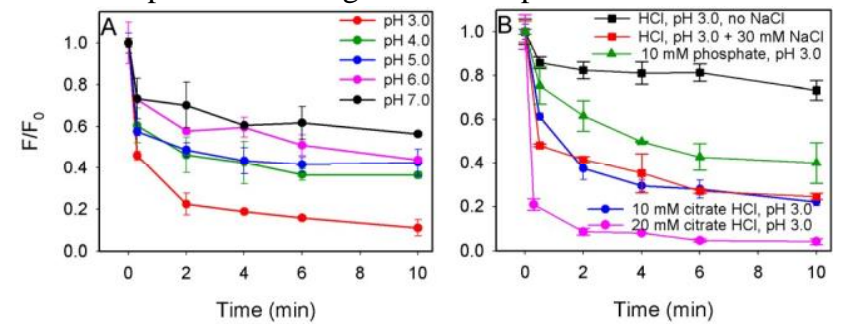

Figure 3. Kinetics of fluorescence decrease indicating DNA adsorption as a function of $\mathrm{pH}$ (A) and salt (B). In (A) all the buffers contained $10 \mathrm{mM}$ citrate $\cdot \mathrm{HCl}$ and therefore $30 \mathrm{mM} \mathrm{Na}^{+}$.

Since citrate is one of the components in the AuNP solution, using citrate buffer for $\mathrm{pH}$ adjustment avoids interference. For mechanistic understanding, we aim to test whether the fast adsorption is a pure $\mathrm{pH}$ effect or citrate itself plays a role. We next used $\mathrm{HCl}$ to adjust $\mathrm{pH}$ to 3.0. Interestingly, after the initial drop of $\sim 20 \%$ fluorescence, further DNA adsorption became much slower (Figure 3B, black squares), suggesting these initially adsorbed DNA hindered further adsorption. The

$10 \mathrm{mM}$ citrate $\cdot \mathrm{HCl}$ buffer contained $30 \mathrm{mM} \mathrm{Na}^{+}$from trisodium citrate, but no additional $\mathrm{Na}^{+}$was present if $\mathrm{pH}$ was adjusted using $\mathrm{HCl}$. For a fair comparison, $30 \mathrm{mM} \mathrm{NaCl}$ was added to the $\mathrm{pH} 3.0 \mathrm{HCl}$ sample and efficient adsorption was then obtained (red squares). Using $10 \mathrm{mM} \mathrm{pH} 3$ phosphate $(\sim 10 \mathrm{mM}$ $\mathrm{Na}^{+}$) produced intermediate adsorption (green triangles). Therefore, both low $\mathrm{pH}$ and salt were required for fast adsorption. If $20 \mathrm{mM}$ of $\mathrm{pH} 3.0$ citrate $\cdot \mathrm{HCl}$ buffer was added (i.e. $60 \mathrm{mM} \mathrm{Na}$ ), $\sim 100 \%$ adsorption was achieved in $2 \mathrm{~min}$ (pink dots), further confirming the role of salt concentration.

All the above experiments were performed by mixing DNA and AuNPs before adjusting $\mathrm{pH}$. In the absence of DNA, we noticed that if $\mathrm{HCl}$ was used, AuNPs were stable even at $\mathrm{pH}$ 3.0. If citrate $\cdot \mathrm{HCl}$ was used, however, AuNPs changed color to blue right away (Figure S1, Supporting Information). This again indicated the effect of salt. Since $\mathrm{HCl}$ is volatile, we employed citrate $\cdot \mathrm{HCl}$ buffer for subsequent studies.

To test whether the AuNPs were homogeneously functionalized with such a short incubation time at low $\mathrm{pH}$, DNA8 was mixed with AuNPs at various $\mathrm{pH}$ for $10 \mathrm{~min}$ and then the samples were analyzed using gel electrophoresis (Figure 4A). The sample at pH 3.0 migrated as a single sharp band, indicating that each AuNP contained roughly the same number of DNA. The samples at $\mathrm{pH} 7$ and 8, however, were smeared, suggesting a wide distribution of DNA density. The same gel was also imaged using UV light excitation to observe fluorescence from non-conjugated free DNAs (Figure 4B, white 
bands). The pH 3 sample had almost no free DNA, suggesting high literature. ${ }^{12}$ A high DNA loading is one of the most important adsorption efficiency. The higher $\mathrm{pH}$ samples showed more free features of such DNA-functionalized AuNPs, giving DNA, consistent with the previous kinetic data. In this imaging multivalent binding and cooperative melting. However, if the mode, AuNPs appeared to be dark bands since they absorbed UV DNA density is too high, it may also inhibit DNA light.
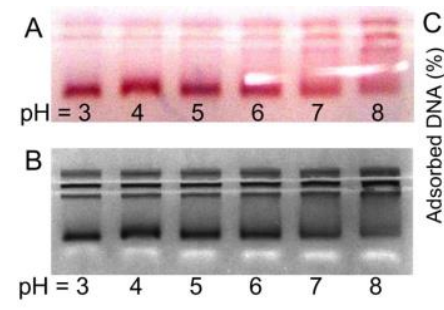
hybridization. $^{22}$

To ensure that conjugates prepared at low $\mathrm{pH}$ were functional, we tested DNA-directed assembly of AuNPs. The AuNPs were prepared by respectively mixing with DNA1 and DNA3 followed by adjusting $\mathrm{pH}$ to 3.0 for $3 \mathrm{~min}$. For comparison, the normal salt aged samples were also prepared. In both cases, AuNPs changed color to purple in a few minutes after adding linker DNA (data not shown), indicating AuNP aggregation. Upon increasing temperature, sharp melting transitions were observed (Figure S3), which is one of the hallmarks of such

Figure 4. Gel electrophoresis of AuNPs mixed with DNA8 in buffers of DNA-linked AuNPs. ${ }^{10}$ Therefore, our pH method generates various pH. (A) Picture taken using a digital camera and AuNPs are red. fully functional AuNPs.

(B) Picture taken using a gel documentation system with UV excitation. The free DNA appears as white bands; the AuNPs appear black. (C) Percentage of adsorbed DNA as a function of DNA-to-AuNP ratio at $\mathrm{pH} 3$ in $20 \mathrm{mM}$ citrate $\mathrm{HCl}$ buffer. Inset: photographs of AuNPs in $\mathrm{pH}$ 3 citrate $\mathrm{CHCl}$ (no additional $\mathrm{NaCl})$ and $\mathrm{pH} 7(100 \mathrm{mM} \mathrm{NaCl}$ added a few minutes after adding DNA and AuNPs aggregated).

In the above kinetic experiments, a DNA:AuNP ratio of 75:1 was used and quantitative adsorption was achieved with

$20 \mathrm{mM}$ citrate $\cdot \mathrm{HCl}$. Quantitative adsorption is important for applications where a designated number of DNA need to be adsorbed, or a mixture of different DNAs need to be loaded at a certain ratio. To further characterize DNA adsorption, the DNA-toAuNP ratio was varied from 20 to 150 . Close to quantitative adsorption was observed up to a ratio of 80 (Figure 4C). After that, more free DNAs were observed due to surface saturation. Such experiments cannot be carried out by adding salt at neutral $\mathrm{pH}$ in the absence of surfactants since the addition of even $50-100 \mathrm{mM} \mathrm{NaCl}$ (e.g. typical for salt aging) induced AuNP aggregation even at a relatively high DNA-toAuNP ratio (inset of Figure $4 \mathrm{C}$ and see Figure S2 for UV-vis spectra). This may explain why in the saltaging method, DNA is always used in great excess and a long incubation time is needed. We have previously studied DNA adsorption as a function of $\mathrm{NaCl}$ concentration at neutral $\mathrm{pH}$, where $<20$ nonthiolated DNAs were adsorbed in the presence $90 \mathrm{mM}$ $\mathrm{NaCl}^{24}$ Adsorbed DNA posed a strong repulsive barrier for incoming DNA, thus limiting the loading capacity. At pH 3, A and C bases are positively charged and even citrate is partially protonated, reducing charge repulsion with AuNPs and among DNA and allowing for fast adsorption.

Our results imply the fundamental reaction kinetics during AuNP functionalization. The negative charges on citrate capped AuNPs are essential for their colloidal stability, which also retard DNA adsorption. To achieve DNA attachment while still maintaining good dispersion of AuNPs, DNA adsorption needs to proceed before AuNP aggregation. In the salt aging method, the kinetics of DNA adsorption needs to be accelerated by a high DNA concentration. In other words, at neutral $\mathrm{pH}$ if DNA concentration is low, AuNPs aggregate before DNA is attached upon adding salt. At low $\mathrm{pH}$, it is possible to achieve DNA binds to AuNPs before AuNP aggregate even when the DNA concentration is low (e.g. 20:1).

So far, we have established that low $\mathrm{pH}$ is essential for fast DNA adsorption. To test whether low $\mathrm{pH}$ has any effect on adsorption capacity, DNA8 and $13 \mathrm{~nm}$ AuNPs were incubated at a ratio of 200:1 in $\mathrm{pH} 3$ and 7 , respectively. The $\mathrm{Na}^{+}$concentrations were adjusted to 30,100 , and $300 \mathrm{mM}$ and the adsorbed DNAs were quantified (Figure 5A). At each salt concentration, the capacity of DNA at $\mathrm{pH}$ 3 was $\sim 30 \%$ higher than that at $\mathrm{pH} 7$. Higher $\mathrm{NaCl}$ concentrations resulted in increased capacity at both $\mathrm{pH}$ 's, consistent with the
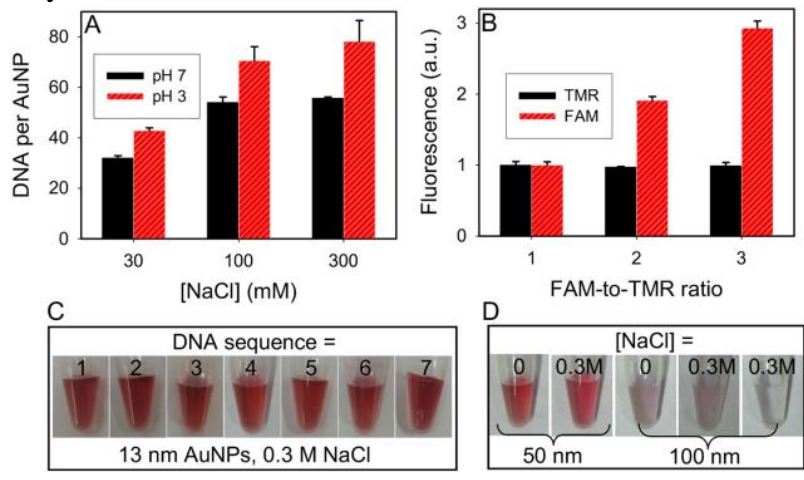

Figure 5. (A) DNA adsorption capacity as a function of $\mathrm{pH}$ and salt concentration. (B) Attachment of two DNAs at different ratios. (C) AuNPs attached with different DNA sequences at pH 3 with 300 $\mathrm{mM} \mathrm{NaCl}$. (D) Functionalization of 50 and $100 \mathrm{~nm}$ AuNPs with DNA10. The last tube did not contain any DNA.

Next we aim to test whether this method is general to other DNA sequences. A total of seven thiolated DNAs were used (see Figure 1C for DNA sequences) including ones with polyA spacer, poly-T spacer, and various fluorophores. The length of DNA also varied from 12 to 35 nucleotides; all showed good protection just several minutes after adjusting $\mathrm{pH}$ to 3

(Figure 5C), confirming good generality to DNA sequence. Using DNA10, AuNPs of 50 and $100 \mathrm{~nm}$ were functionalized at $\mathrm{pH}$ 3(Figure 5D). Both showed color similar to the control samples where no $\mathrm{NaCl}$ was added. The $100 \mathrm{~nm}$ sample was purple even in the absence of salt. If $\mathrm{NaCl}$ was added in the absence of DNA, the tube turned clear immediately (the last tube in Figure 5D; see Figure S4 for UV-vis spectra). Therefore, fast adsorption of DNA at low $\mathrm{pH}$ is also generally applicable to various AuNP sizes.

For more advanced applications, it is often desirable to attach multiple different DNAs at designated ratios. ${ }^{27}$ Current methods employ an excess amount of DNA, disallowing a rigorous control on the final ratio of adsorbed DNA. ${ }^{27 \mathrm{c}}$ In this regard, quantitative DNA adsorption at low $\mathrm{pH}$ might be useful to achieve this goal. To test this, we mixed DNA 8 and DNA9 at $1: 1,2: 1$ and $3: 1$ ratios, where the DNA9-to-AuNP ratio was maintained at 15:1. The fluorescence recovered after releasing the DNAs from AuNPs was measured and all showed similar TMR fluorescence but the FAM intensity followed a 3:2:1 pattern (Figure 5B). Therefore, multiplexed functionalization with precise density control was achieved.

In summary, we reported a facile method for instantaneous attachment of thiolated DNA to AuNPs using a low pH buffer. 
The whole process takes just a few minutes, as compared to 12 days of using the salt-aging protocol. The produced AuNP/DNA conjugates are homogeneous and functional. This method is general to a wide range of AuNP sizes and DNA sequences. One important feature is to achieve quantitative DNA adsorption and maintain AuNP stability even at low DNA density, allowing the adsorption of designated numbers of DNA and the attachment of multiple DNAs at designated ratios. While the salt-aging method has driven the development of nanobiotechnology in the past 16 years, these new features brought by the low $\mathrm{pH}$ method will enable more applications. In addition to its technical importance, our work also has fundamental implications that can impact many other fields of research. For example, in colloidal and surface science, while electrostatic interactions can be controlled by either using high salt to reduce the Debye length or using low $\mathrm{pH}$ to reduce the surface charge density, this study reveals a possible synergistic effect between these two factors. So far, most of the work on DNAfunctionalized AuNPs has been carried out at close to neutral $\mathrm{pH}$. Our results indicated that $\mathrm{pH}$ provides a new way to tune the interaction between DNA and AuNPs.

Supporting Information. Materials and methods, melting curves, UVvis spectra, and AuNP stability assays. "This material is available free of charge via the Internet at http://pubs.acs.org."

\section{AUTHOR INFORMATION}

\section{Corresponding Author}

liujw@uwaterloo.ca

\section{ACKNOWLEDGMENT}

Funding for this work is from the University of Waterloo, the Canadian Foundation for Innovation, Early Researcher Award from Ontario Ministry of Research \& Innovation, Canadian Institutes of Health Research, and the Discovery Grant of the Natural Sciences and Engineering Research Council (NSERC) of Canada.

\section{REFERENCES}

(1) Mirkin, C. A.; Letsinger, R. L.; Mucic, R. C.; Storhoff, J. J. Nature 1996, 382, 607-609.

(2) Alivisatos, A. P.; Johnsson, K. P.; Peng, X.; Wilson, T. E.; Loweth, C. J.; Bruchez, M. P., Jr; Schultz, P. G. Nature 1996, 382, 609-611.

(3) (a) Storhoff, J. J.; Mirkin, C. A., Chem. Rev. 1999, 99, 18491862. (b) Park, S. Y.; Lytton-Jean, A. K. R.; Lee, B.; Weigand, S.; Schatz, G. C.; Mirkin, C. A., Nature 2008, 451, 553-556. (c) Nykypanchuk, D.; Maye, M. M.; van der Lelie, D.; Gang, O., Nature 2008, 451, 549-552. (d) Pinheiro, A. V.; Han, D.; Shih, W. M.; Yan, H., Nat Nano 2011, 6, 763-772. (e) Sharma, J.; Chhabra, R.; Cheng, A.; Brownell, J.; Liu, Y.; Yan, H., Science 2009, 323, 112-116. (f) Katz, E.; Willner, I., Angew. Chem., Int. Ed. 2004, 43, 6042-6108. (g) Maye, M. M.; Kumara, M. T.; Nykypanchuk, D.; Sherman, W. B.; Gang, O. Nat. Nanotechnol. 2010, 5, 116-120. (h) Seeman, N. C. Nature 2003, 421, 427-431. (i) Aldaye, F. A.; Palmer, A. L.; Sleiman, H. F. Science 2008, 321, 1795-1799. (j) Gao, Y.; Tang, Z., Small 2011, 7, 2133-2146.

(4) (a) Rosi, N. L.; Mirkin, C. A., Chem. Rev. 2005, 105, 15471562. (b) Liu, J.; Cao, Z.; Lu, Y., Chem. Rev. 2009, 109, 1948-1998. (c) Zhao, W.; Brook, M. A.; Li, Y., Chembiochem 2008, 9, 2363 2371. (d) Li, D.; Song, S. P.; Fan, C. H., Acc. Chem. Res. 2010, 43, 631-641. (e) Guo, S. J.; Dong, S. J., Trends Anal. Chem. 2009, 28 , 96-109. (f) Lubin, A. A.; Plaxco, K. W., Acc. Chem. Res. 2010, 43, 496-505. (g) Wang, H.; Yang, R. H.; Yang, L.; Tan, W. H., ACS Nano 2009, 3, 2451-2460. (h) Liu, D. B.; Wang, Z.; Jiang, X. Y., Nanoscale 2011, 3, 1421-1433. (i) Agasti, S. S.; Rana, S.; Park, M. H.; Kim, C. K.; You, C. C.; Rotello, V. M. Adv. Drug Deliver. Rev. 2010, 62, 316-328.

(5) Zheng, M.; Jagota, A.; Strano, M. S.; Santos, A. P.; Barone, P.; Chou, S. G.; Diner, B. A.; Dresselhaus, M. S.; McLean, R. S.; Onoa, G. B.;
Samsonidze, G. G.; Semke, E. D.; Usrey, M.; Walls, D. J. Science 2003, 302, 1545-1548.

(6) Giljohann, D. A.; Seferos, D. S.; Daniel, W. L.; Massich, M. D.; Patel, P. C.; Mirkin, C. A. Angew. Chem. Int. Ed. 2010, 49, 32803294

(7) (a) Chen, Y.; O'Donoghue, M. B.; Huang, Y. F.; Kang, H. Z.; Phillips, J. A.; Chen, X. L.; Estevez, M. C.; Yang, C. Y. J.; Tan, W. H., J. Am. Chem. Soc. 2010, 132, 16559-16570. (b) Dutta, P. K.; Varghese, R.; Nangreave, J.; Lin, S.; Yan, H.; Liu, Y., J. Am. Chem. Soc. 2011, 133, 11985-11993. (c) Hamad-Schifferli, K.; Schwartz, J.

J.; Santos, A. T.; Zhang, S.; Jacobson, J. M., Nature 2002, 415, 152155. (d) Strouse, G. F., J. Am. Chem. Soc. 2005, 127, 31153119. (e) Dave, N.; Liu, J., Adv. Mater. 2011, 23, 3182-3186. (f) Huang, P.-J. J.; Liu, J. Small 2012, 8, 977-983.

(8) (a) Hurst, S. J.; Hill, H. D.; Mirkin, C. A. J. Am. Chem. Soc. 2008 130, 12192-12200. (b) Rinker, S.; Ke, Y. G.; Liu, Y.; Chhabra, R.; Yan, H. Nat. Nanotechnol. 2008, 3, 418-422. (c) Dave, N.; Liu, J., ACS Nano 2011, 5, 1304-1312.

(9) Storhoff, J. J.; Elghanian, R.; Mucic, R. C.; Mirkin, C. A.; Letsinger, R. L. J. Am. Chem. Soc. 1998, 120, 1959-1964.

(10) (a) Elghanian, R.; Storhoff, J. J.; Mucic, R. C.; Letsinger, R. L.; Mirkin, C. A., Science 1997, 277, 1078-1080. (b) Cutler, J. I.; Auyeung, E.; Mirkin, C. A. J. Am. Chem. Soc. 2012, 134, 13761391.

(11) Li, Z.; Cheng, E.; Huang, W.; Zhang, T.; Yang, Z.; Liu, D.; Tang, Z. J. Am. Chem. Soc. 2011, 133, 15284-15287.

(12) Hurst, S. J.; Lytton-Jean, A. K. R.; Mirkin, C. A. Anal. Chem. 2006, $78,8313-8318$.

(13) Herne, T. M.; Tarlov, M. J. J. Am. Chem. Soc. 1997, 119, 89168920.

(14) Demers, L. M.; Mirkin, C. A.; Mucic, R. C.; Reynolds, R. A., III; Letsinger, R. L.; Elghanian, R.; Viswanadham, G. Anal. Chem. 2000, 72, 5535-5541.

(15) Liu, J.; Lu, Y. Nat. Protoc. 2006, 1, 246-252.

(16) Hill, H. D.; Millstone, J. E.; Banholzer, M. J.; Mirkin, C. A. ACS Nano 2009, 3, 418-424.

(17) Herdt, A. R.; Drawz, S. M.; Kang, Y. J.; Taton, T. A. Colloid. Surface. B. 2006, 51, 130-139.

(18) Bhatt, N.; Huang, P.-J. J.; Dave, N.; Liu, J. Langmuir 2011, 27, 6132-6137.

(19) Jin, R.; Wu, G.; Li, Z.; Mirkin, C. A.; Schatz, G. C. J. Am. Chem. Soc. 2003, 125, 1643-1654.

(20) Liu, J.; Lu, Y. J. Am. Chem. Soc. 2004, 126, 12298-12305.

(21) Zaki, A.; Dave, N.; Liu, J. J. Am. Chem. Soc. 2012, 134, 35-38.

(22) Zu, Y.; Gao, Z. Anal. Chem. 2009, 81, 8523-8528.

(23) Zu, Y.; Ting, A. L.; Yi, G.; Gao, Z. Anal. Chem. 2011, 83, 40904094

(24) Zhang, X.; Servos, M. R.; Liu, J. Langmuir 2012, 28, 38963902.

(25) Nelson, E. M.; Rothberg, L. J. Langmuir 2011, 27, 1770-1777.

(26) Sun, L. P.; Zhang, Z. W.; Wang, S.; Zhang, J. F.; Li, H.; Ren, L.; Weng, J.; Zhang, Q. Q. Nanoscale Res. Lett. 2009, 4, 216-220.

(27) (a) Nam, J.-M.; Stoeva, S. I.; Mirkin, C. A., J. Am. Chem. Soc. 2004, 126, 5932-5933. (b) Song, S. P.; Liang, Z. Q.; Zhang, J.; Wang, L. H.; Li, G. X.; Fan, C. H., Angew. Chem. Int. Ed. 2009, 48, 86708674. (c) Díaz, J. A.; Grewer, D. M.; Gibbs-Davis, J. M. Small 2012, 8, 873-883. (d) Xing, H.; Wang, Z.; Xu, Z.; Wong, N. Y.; Xiang, Y.; Liu, G. L.; Lu, Y. ACS Nano 2012, 6, 802-809. 